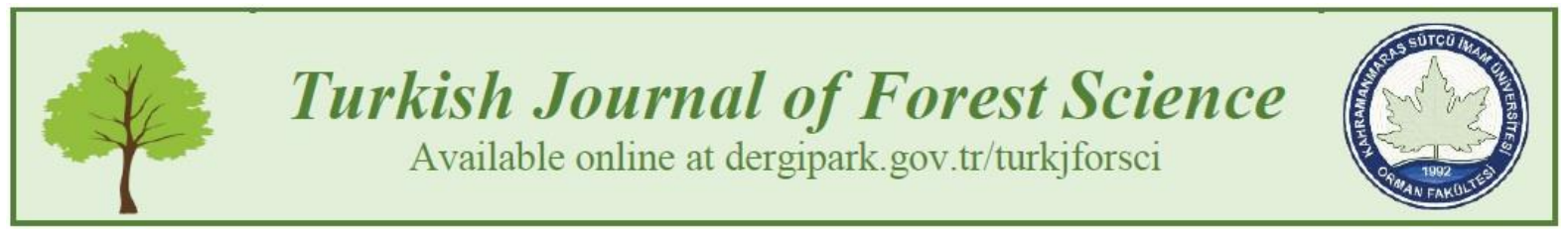

\title{
AUTOMATED LAND SURFACE TEMPERATURE RETRIEVAL FROM LANDSAT 8 SATELLITE IMAGERY: A CASE STUDY OF DIYARBAKIR - TURKEY
}

\author{
Hakan OGUZ* \\ Department of Landscape Architecture, Faculty of Forestry, Kahramanmaras Sutcu Imam University, \\ Kahramanmaras \\ *Corresponding author: hakan@ksu.edu.tr
}

ARTICLE INFO

Research Article

Received 8 March 2017

Received in revised form 28 April 2017

Accepted 29 April 2017

\begin{abstract}
Land Surface Temperature (LST) is an essential climate parameter, related to surface energy balance. The new instrument which was called Thermal Infrared Sensor (TIRS) carried on board of the new generation of Landsat 8 captures the temperature of the Earth's surface in two bands, band 10 and band 11 with spatial resolution of $100 \mathrm{~m}$. The main objective of this study was to develop a tool making the LST retrieval process quite simple and automated. In this study, Radiative Transfer Equation (RTE) method has been employed in ArcGIS Model Builder to retrieve LST from Landsat 8 satellite imagery. The user just inputs required bands (Band4, Band5, and Band10) and a couple of parameters then the tool outputs the final LST imagery automatically. The tool first makes the conversions to top of atmosphere (TOA) radiance and reflectance. Then NDVI is calculated based on NIR and RED bands reflectances. Land surface emissivity is calculated based on NDVI Thresholds Method (NDVI-THM) which was developed by Sobrino et al. (2008). Finally, the tool calculates land surface temperatures in degrees Celsius.
\end{abstract}

Keywords: ArcGIS, Model Builder, GIS, NDVI, Emissivity

\section{LANDSAT 8 UYDU GÖRÜNTÜSÜNDEN OTOMATIK YER YÜZEY SICAKLIĞI ELDESİ: DIYYARBAKIR - TÜRKIYYE ÖRNEĞİ}

ESER BILGISI

Araştırma Makalesi

Gelis 8 Mart 2017

Düzeltmelerin Gelişi 28 Nisan 2017

Kabul 29 Nisan 2017

ÖZET: Yer yüzey sıcaklığı (YYS) yüzey enerji dengesi açısından çok önemli bir parametredir. Termal sensöre sahip olan yeni jenerasyon Landsat 8 uydusu dünyanın yüzey sicaklığını $100 \mathrm{~m}$ konumsal çözünürlüğe sahip termal iki bant (bant 10 ve bant 11) sayesinde elde etmektedir. Bu çalışmanın ana amacı YYS hesaplamasını kolay ve otomatik yapan bir araç geliştirmektir. Bu çalışmada geliştirilen araç Landsat 8 uydu görüntüsünden YYS'nın hesaplanmasında Radiative Transfer Equation (RTE) yöntemini kullanılmıştır. Kullanıcı sadece bant 4, bant 5 ve bant 10 ile birkaç parametre girdikten sonar YYS otomatik olarak elde edilmektedir. Bu araç önce radyans ve yüzey yansıması için atmosfer üstü dönüşümlerini This is an extended and revised version of a preliminary conference report that was presented at the International Diyarbakir Symposium, held in Diyarbakir, Turkey from 2 to 5 November 2016. 
yapmaktadır. Normalize edilmiş vejetasyon indeksi (NDVI) kırmızı ve yakın kızılötesi natlarının yüzey yansıma değerleri kullanılarak hesaplanmıştır. Sobrino et al. (2008) tarafından geliştirilen NDVI threshols yöntemi kullanılarak yer yüzey yayınırlığ 1 hesaplanmıştır. Son olarak, geliştirilen araç YYS'nı ${ }^{\circ} \mathrm{C}$ olarak hesaplamaktadır.

Anahtar Kelimeler: ArcGIS, Model Builder, CBS, NDVI, Yayınırlık

\section{INTRODUCTION}

Land surface temperature (LST) is one of the most important parameters in climate change, evapotranspiration, urban climate, vegetation monitoring and environmental studies. LST can be described as the temperature of the earth's surface. As well known, it is not easy to retrieve land surface temperature for large areas with the help of remote sensing (Li et al. 2013). Several methods have been developed till now but single-channel (SC), split-window (SW) and radiative transfer equation (RTE) are the most popular methods among them. In the last couple of decades, many studies have been carried out on thermal analysis using MODIS, ASTER, Landsat TM/ETM and Landsat 8 data (Li et al 2013, Barsi et al 2003, Cristobal et al 2009, Jiménez-Muñoz, and Sobrino 2008, Jiménez-Muñoz et al 2009, Oguz 2013, Oguz 2015, Oguz 2016a, Oguz 2016b).

In this study, a tool developed by Oguz (2016) in ArcGIS Model Builder was used to calculate LST from Landsat 8 satellite imagery using the RTE method. The tool requires band4, band5, and band10 as input to compute the LST automatically.

\section{MATERIALS AND METHODS}

\section{Input Data}

Landsat 8 satellite imagery acquired on August 31st 2016 (path/row: 172/34) was used as input data in this study. The temporal resolution of Landsat 8 is 16 days and can be downloaded from USGS webpage for free (USGS 2016). The instrument has two sensors: the operational land imager (OLI) and thermal infrared sensor (TIRS). OLI sensor has 9 bands with $30 \mathrm{~m}$ spatial resolution (except for panchromatic band) and the TIR sensor has two thermal bands with 100m spatial resolution as illustrated in Table 1 below (LDUH 2016). 
Table 1 The band characteristics for Landsat 8

\begin{tabular}{lllc}
\hline Band Number & Band Width & Description & Resolution $(\mathrm{m})$ \\
\hline Band 1 & $0.435-0.451$ & Coastal/Aerosol & 30 \\
Band 2 & $0.452-0.512$ & Blue & 30 \\
Band 3 & $0.533-0.590$ & Green & 30 \\
Band 4 & $0.636-0.673$ & Red & 30 \\
Band 5 & $0.851-0.879$ & NIR & 30 \\
Band 6 & $1.566-1.651$ & SWIR-1 & 30 \\
Band 7 & $2.107-2.294$ & SWIR-2 & 30 \\
Band 8 & $0.503-0.676$ & Pan & 15 \\
Band 9 & $1.363-1.384$ & Cirrus & 30 \\
Band 10 & $10.60-11.19$ & TIR-1 & 100 \\
Band 11 & $11.50-12.51$ & TIR-2 & 100 \\
\hline
\end{tabular}

\section{Study Area}

Diyarbakir was selected as the study area in this research. Diyarbakir is located in the southeastern part of Turkey and the second largest city after Gaziantep in the southeastern Anatolia region. The city was founded on the banks of the Tigris River. Diyarbakir is also a tourism destination. Diyarbakir!s city walls and archaeological excavations are of great historical importance. The city has a population of about 1.6 million according to 2015 census. The climate in Diyarbakir is classified as continental, summers are very hot, but winters are cool and rainy. The long term average annual temperature and precipitation were $15.8^{\circ} \mathrm{C}$ and $490 \mathrm{~mm}$ respectively (TSMS 2016).

Landsat 8 scene with path/row: 172/34 acquired on 31st August 2016 was downloaded from USGS (2016) website. Figures 1 below illustrates the location of the study area with Landsat 8 satellite imagery. 


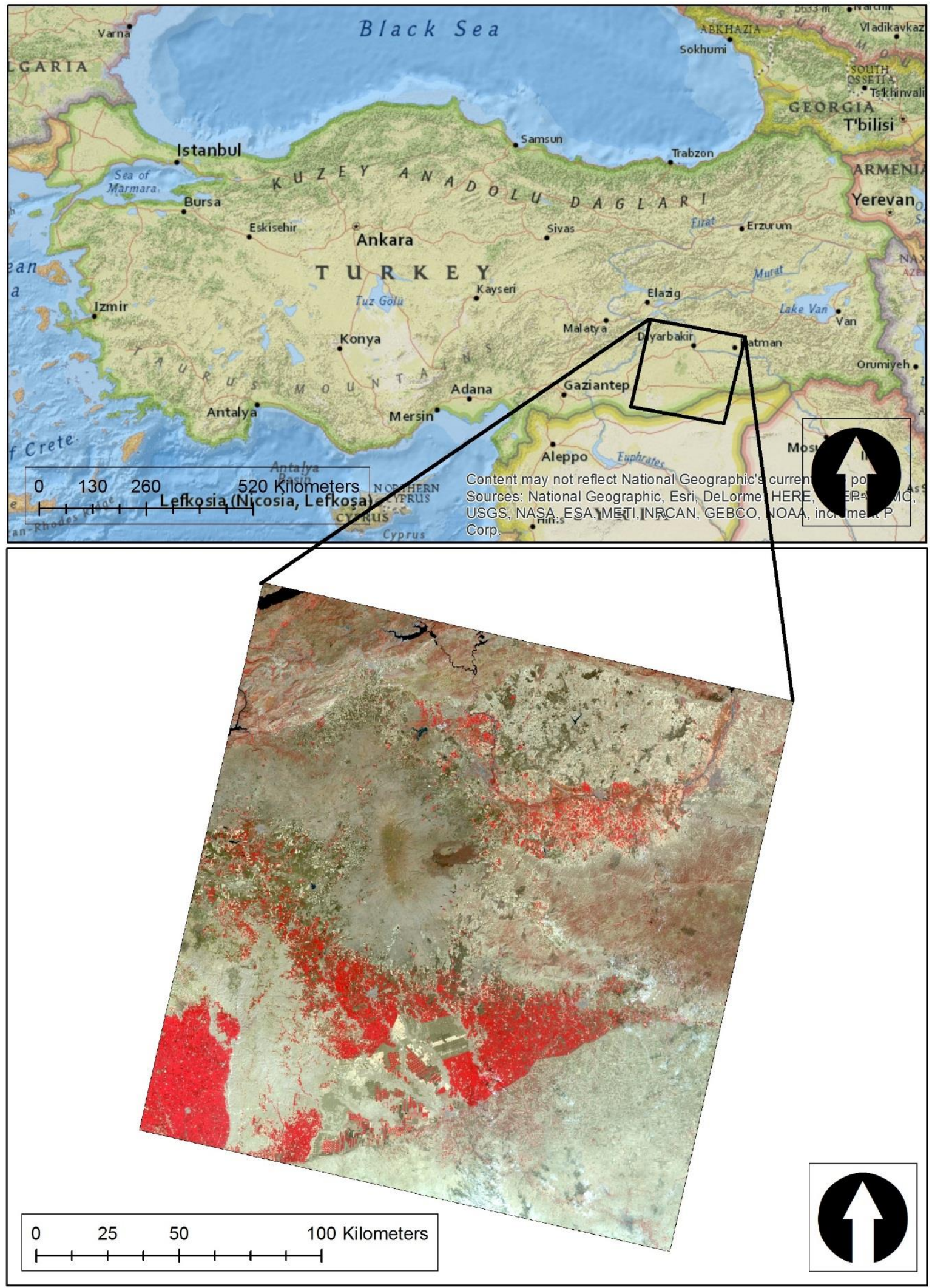

Figure 1. Location map of the study area 


\section{The Method}

Since the RTE method was found as the most accurate method by (Yu et al 2014, it was employed in this study.

$T_{s}=\left[\frac{c_{2}}{\lambda \ln \left[\frac{c_{1}}{\lambda^{5}\left[\frac{\left.l_{\operatorname{sen}}-l_{u}-\tau(1-\varepsilon) l_{d}\right]}{\tau \varepsilon}+1\right.}\right]}\right]$

where Ts is the land surface temperature, $\lambda$ is the effective band wavelength, lsen is the thermal radiance at sensor level, lu is the upwelling atmospheric radiance, ld is the downwelling atmospheric radiance, $\tau$ is the atmospheric transmissivity, $\varepsilon$ is the land surface emissivity, and $\mathrm{c} 1$ and $\mathrm{c} 2$ are constants.

$l_{\operatorname{sen}}=\left[\varepsilon B_{T_{s}}+(1-\varepsilon) l_{d}\right] \tau+l_{u}$

where B_(T_s ) corresponds the radiance of plank's law.

Land surface emissivity is calculated from Landsat 8 VNIR bands based on Fractional Vegetation Cover (FVC) for a given pixel (Sobrino et al 2008).

$F V C=\left[\frac{N D V I-N D V I_{s}}{N D V I_{v}-N D V I_{s}}\right]$

where NDVIs and NDVIv correspond to NDVI values for bare soil and vegetation respectively. Emissivity values were calculated based on FVC value as follows:

$$
\begin{array}{ll}
\mathrm{FVC}=0 & \varepsilon=0.979-0.04 \rho_{\text {red }} \\
0 \leq \mathrm{FVC} \leq 1 & \varepsilon=0.971(1-\mathrm{FVC})+0.987 \mathrm{FVC} \\
\mathrm{FVC}=1 & \varepsilon=0.99
\end{array}
$$

where $\rho$ _red corresponds to reflectance in the red band (Skokovic et al 2014). The flow diagram of the model is illustrated in Figure 2 below. 


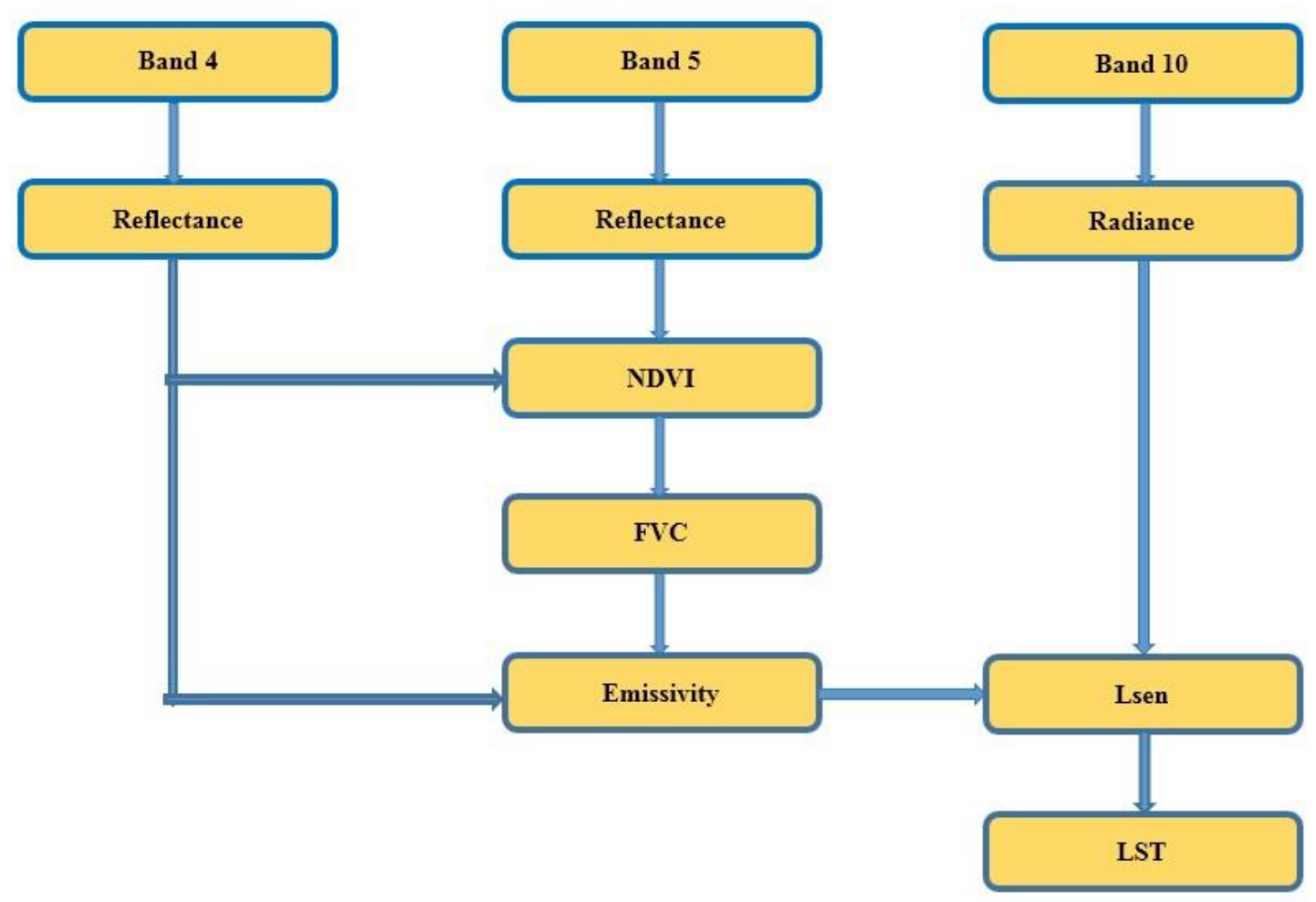

Figure 2. Flow diagram of the model

\section{RESULTS AND DISCUSSION}

In this study, the tool developed by Oguz (2016) was employed in order to calculate LST from Landsat 8 imagery automatically. The input menu interface of the tool is illustrated in Figure 3 below.

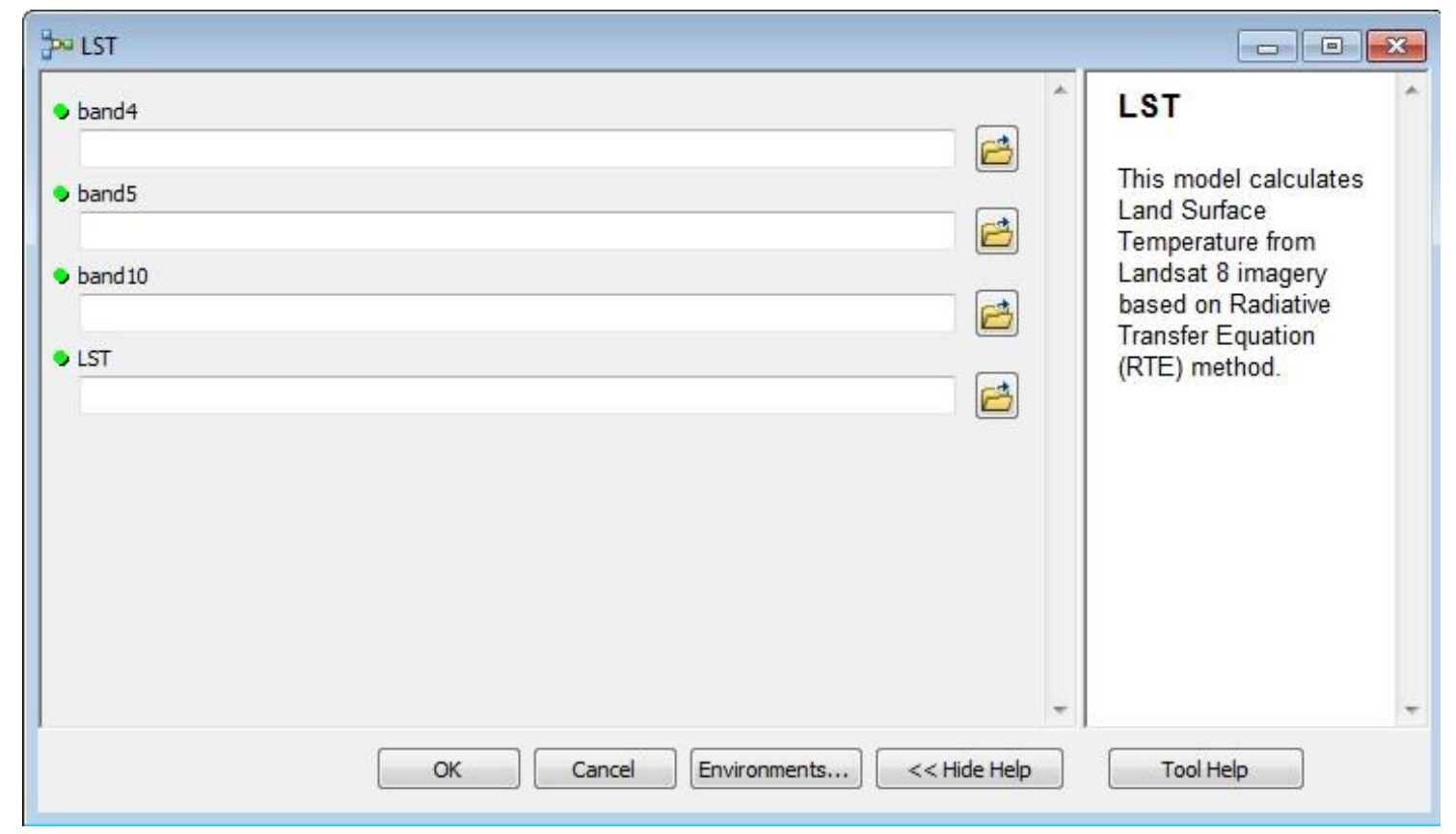

Figure 3. Input menu interface of the tool 
Landsat 8 scene with path/row: 172/34 acquired on 31st August 2016 was used for the demonstration purposes. As shown in Figure 3 above, only three bands (band 4, band 5, and band 10) are required to run the model successfully.

The final LST map of Landsat 8 scene is calculated automatically as illustrated in Figure 4 below after inputting required bands into the LST tool. $44{ }^{\circ} \mathrm{C}$ and $15{ }^{\circ} \mathrm{C}$ were found to be the highest and lowest temperatures in the scene respectively. Northern part of the scene was found to be the hottest part due to the bare land/rock formation, and southern part of the scene was found to be the coolest due to the agricultural areas. 


\section{Spatial Distribution of LST in Diyarbakır}

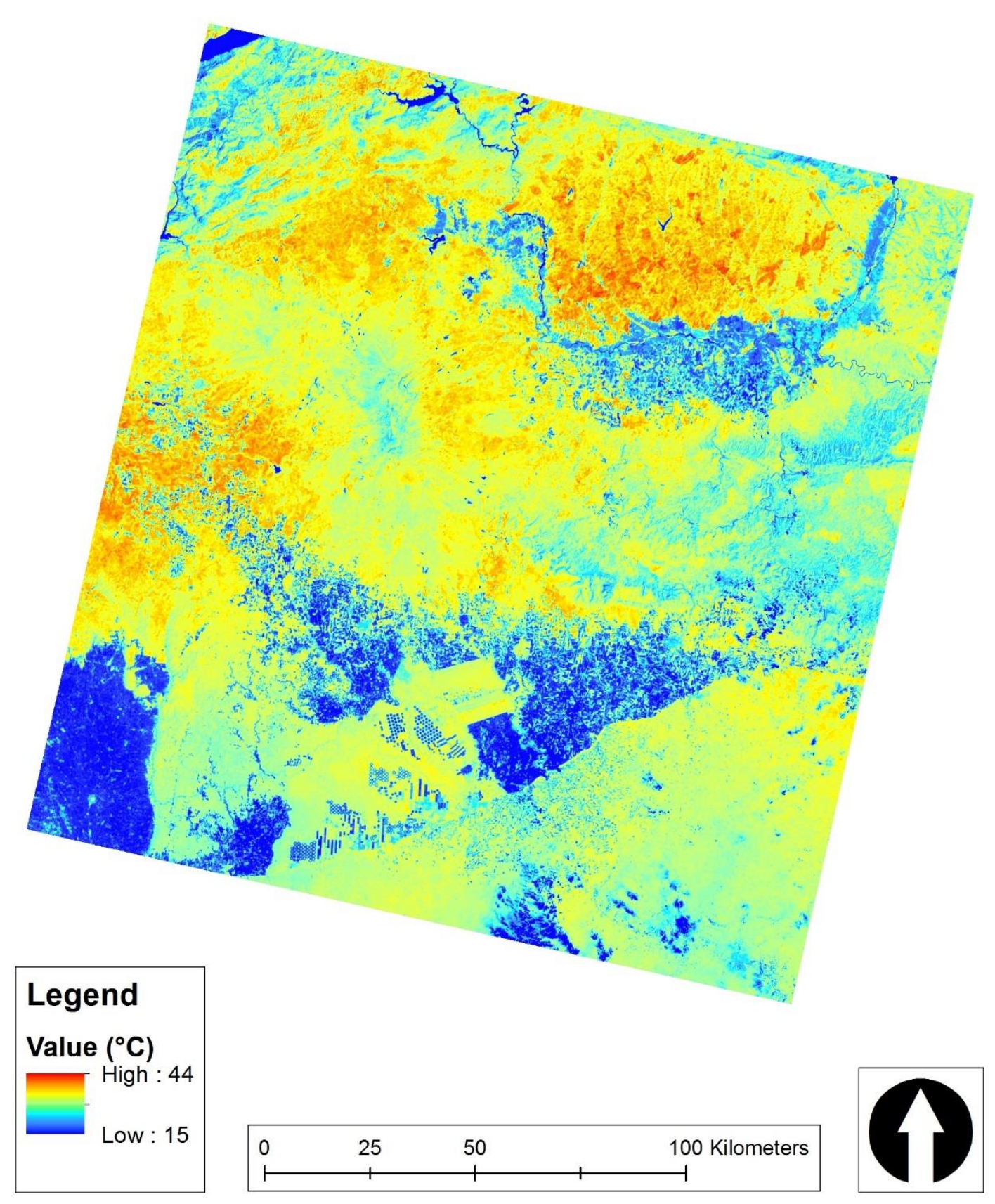

Figure 4. Spatial distribution of LST for the Landsat 8 scene

Afterwards, LST analysis for central district of Diyarbakir was carried out. The final LST map for the central district of Diyarbakir was illustrated in Figure 5 below. 


\section{Spatial Distribution of LST in Diyarbakır District}

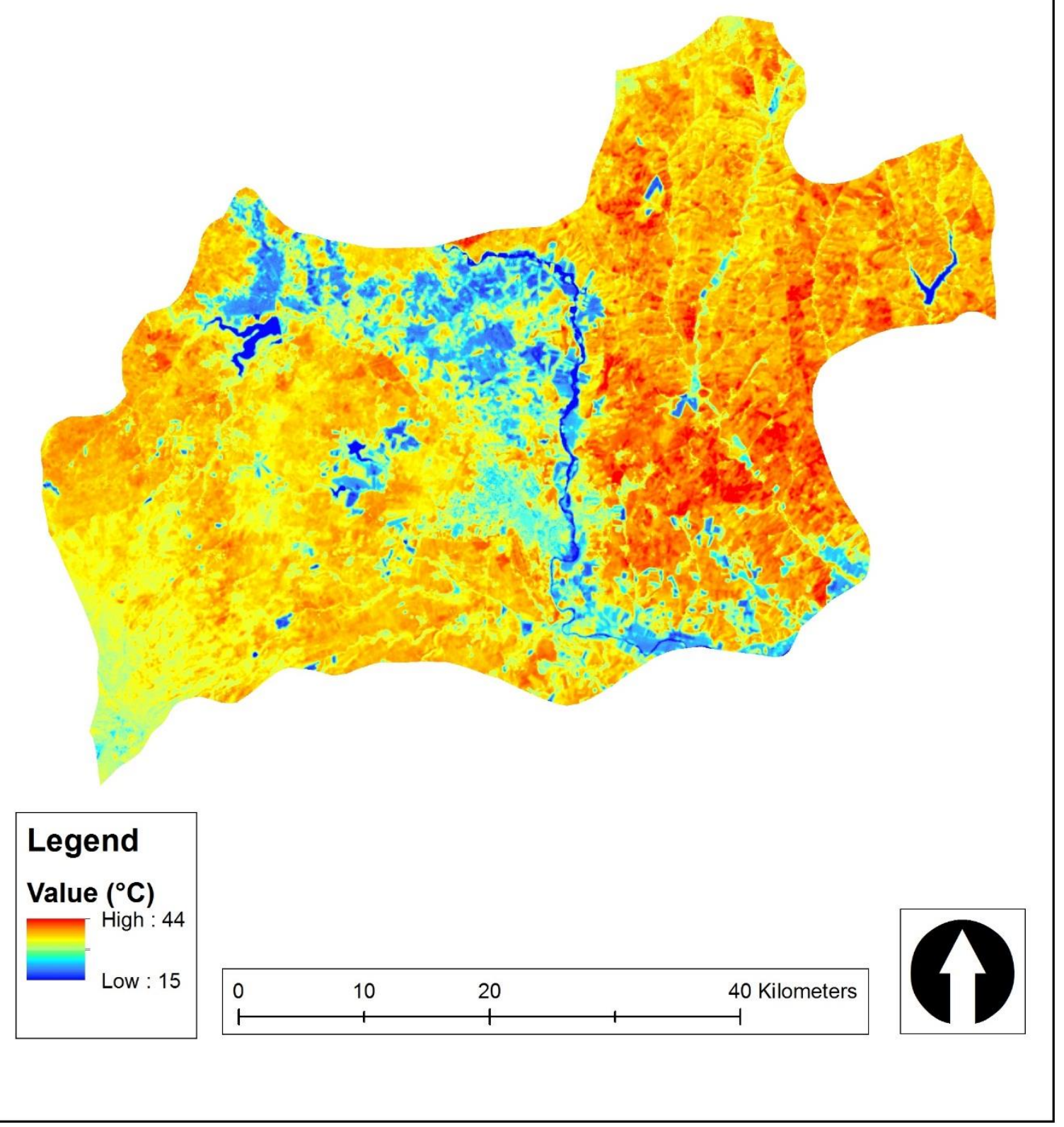

Figure 5. Spatial distribution of LST in the central district of Diyarbakir

As seen in Figure 5 above, the hottest part of the district was found to be the rock formation depicted as red color. Blue toned color represents agricultural land covered with green vegetation and water surfaces. 


\section{CONCLUSIONS}

Land surface temperature is an important parameter in thermal studies. It is not easy to calculate accurate LST in urban thermal environment. Thus, the RTE method has been used in this study due to the high accuracy of the model compare to others. This tool automates the LST calculation and might be helpful to people interested in thermal analysis.

\section{ACKNOWLEDGEMENTS}

The author would like to thank United States Geological Survey (USGS) for providing Landsat-8 images at free of cost.

\section{REFERENCES}

Barsi, J.A., Schott, J.R., Palluconi, F.D., Helder, D.L., Hook, S.J., Markham, B.L., Chander, G., \& O’Donnell E.M. (2003) Landsat TM and ETM+ thermal band calibration. Canadian Journal of Remote Sensing, 29(2), 141-153.

Cristóbal, J., Jiménez-Muñoz, J.C., Sobrino, J.A., Ninyerola, M. \& Pons, X. (2009) Improvements in land surface temperature retrieval from the Landsat series thermal band using water vapor and air temperature. Journal of Geophysical Research, 114(D8), D08103.

Jiménez-Muñoz, J.C., Cristóbal, J., Sobrino, J.A., Sòria, G., Ninyerola, M. \& Pons, X. (2009) Revision of the single-channel algorithm for land surface temperature retrieval from Landsat thermal-infrared data, IEEE Transactions on Geoscience and Remote Sensing, 47(1). 339-349.

Jiménez-Muñoz, J.C. \& Sobrino J.A. (2008) Split-window coefficients for land surface temperature retrieval from low-resolution thermal infrared sensors, IEEE Geoscience and Remote Sensing Letters, 5(4), 806-809.

LDUH (2016) Retrieved October 142016 from https://landsat.usgs.gov/documents/Landsat8DataUsers-Handbook .pdf

Li, Z.L., Tang, B.H., Wu, H., Ren, H., Yan, G., Wan, Z., Trigo, I.F. \& Sobrino J.A. (2013) Satellite-derived land surface temperature: Current status and perspectives, Remote Sensing of Environment, 131, 14-37.

Oguz, H. (2013) LST calculator: A program for retrieving Land Surface Temperature from Landsat TM/ETM+ imagery Environmental engineering and management journal 12(3):549-555.

Oguz, H. (2015) A Software Tool for Retrieving Land Surface Temperature from ASTER Imagery, Journal of Agricultural Sciences. 21, 471-482.

Oguz, H. (2016a) Automated Land Surface Temperature Retrieval from Landsat 8 Satellite Imagery: A Case Study of Kahramanmaras - Turkey. In R. Efe, I. Curebal, A. Gad \& B. Toth (Eds.), Environmental Sustainability and Landscape Management (pp. 598604). St. Kliment Ohridski University Press, Sofia.

Oguz, H. (2016b) LST Calculator: A Python Tool for Retrieving Land Surface Temperature from Landsat 8 Imagery. In R. Efe, I. Curebal, A. Gad \& B. Toth (Eds.), Environmental Sustainability and Landscape Management (pp. 560-572). St. Kliment Ohridski University Press, Sofia. 
Skokovic, D., Sobrino, J.A., Jimenez-Munoz, J.C., Soria, G., Julien, Y., Mattar, C. \& Cristobal, J. (2014) Calibration and Validation of land surface temperature for Landsat 8 - TIRS sensor, European Space Agency Documents.

Sobrino, J.A., Jimenez-Munoz, J.C., Soria, G., Romaguera, M., Guanter, L., Moreno, J., Plaza, A. \& Martincz, P. (2008) Land Surface Emissivity Retrieval from Different VNIR and TIR Sensors, IEEE Transactions on Geoscience and Remote Sensing, 46, 316-27.

TSMS (2016) Retrieved from https://mgm.gov.tr/veridegerlendirme/il-ve-ilceleristatistik.aspx?m=DIYARBAKIR Accessed 01.10.16

USGS, (2016) Retrieved from http://landsat.usgs.gov /landsat8.php Accessed 17.10.2016

Wikipedia (2016) Retrieved from https://en.wikipedia.org/-wiki/Diyarbak\%C4\%B1r Accessed 12.10.16

Yu, X., Guo, X., \& Wu, Z. (2014) Land Surface Temperature Retrieval from Landsat 8 TIRS-Comparison between Radiative Transfer Equation-Based Method, Split Window Algorithm and Single Channel Method, Remote Sensing, 6, 9829-9852. 